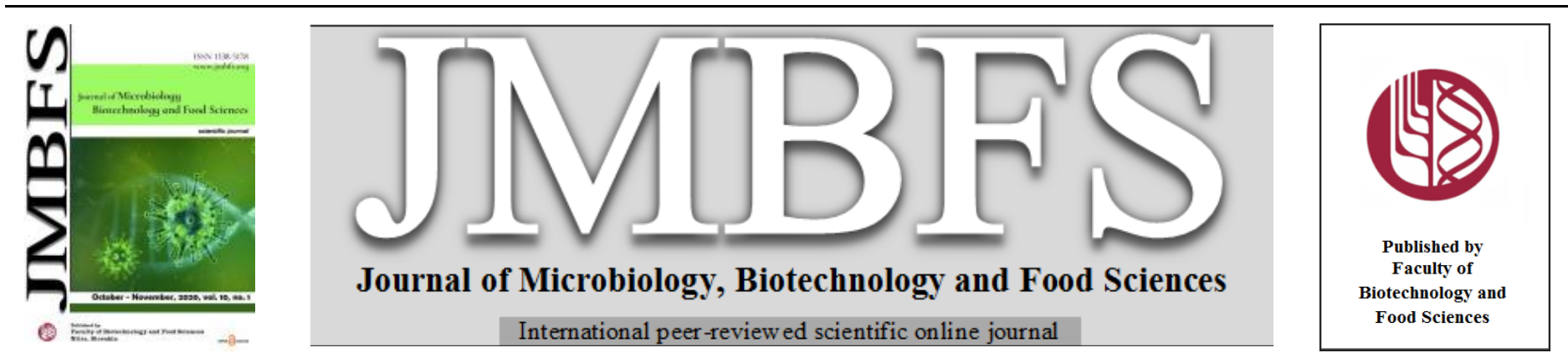

\title{
PROKARYOTIC DIVERSTY OF ACID MINE DRAINAGE PONDS IN ORE ENRICHMENT PLANT
}

\author{
Yağmur TOPTAŞ ${ }^{1}$, Ahmet ÇABUK ${ }^{2,3}$
}

Address(es):

${ }^{1}$ Department of Biology, Graduate School of Natural and Applied Sciences, Eskisehir Osmangazi University, 26480, Eskisehir, Turkey.

${ }^{2}$ Department of Biotechnology and Biosafety, Graduate School of Natural and Applied Sciences, Eskisehir Osmangazi University, 26480, Eskisehir, Turkey.

${ }^{3}$ Department of Biology, Faculty of Arts and Science, Eskisehir Osmangazi University, 26480, Eskisehir, Turkey.

*Corresponding author: yagmurtoptas@gmail.com

doi: 10.15414/jmbfs.2020.10.2.310-316

\section{ARTICLE INFO}

Received 24. 2. 2020

Revised 27. 6. 2020

Accepted 30. 6. 2020

Published 1. 10. 2020

Regular article

open 2 access

\begin{abstract}
The biodiversity of acidophilic prokaryotes was determined in three AMD ponds (pH 2.7-6.5) in Turkey (İzmir-Halıköy antimony ore enrichment plant) using 16S rRNA cloning and denaturing gradient gel electrophoresis methods. Water samples were taken two times in March 2014 and June 2015. The microbial diversity identified includes species such as Acidiphilium angustum, Acidocella sp., Ferroplasma acidiphilum, Acidithiobacillus ferriphilus, Acidithiobacillus ferrivorans, Acidiphilium rubrum, Thiomonas sp., Acidiphilium multivorum, Acidiphilium cryptum, Ferrovum myxofaciens, Acidocella aluminiidurans with the used techniques. In addition to, it has been determined that biodiversity is variable in the operating mine pools. Aciditihobacillus ferriphilus, Acidiphilium angustum, and Acidiphilium rubrum are new records for Turkey.
\end{abstract}

Keywords: acidic mine drainage, acidophiles, prokaryotic diversity, Turkey

\section{INTRODUCTION}

Acid mine drainage (AMD) is the largest environmental problem caused by normally associated with mining activities (Garcia-Moyano et al., 2015). The mining wastewater is defined by properties such as low $\mathrm{pH}$, high metal ions (e.g., iron, nickel, copper) and mineral concentrations. Acidophilic microorganisms living in this habitat are very interesting because of their adaptability to extreme $\mathrm{pH}$ values, their metabolic diversity, and their ability to be used in biomining applications. Especially, due to their availability in biomining and bioremediation applications, it is important to identify the acidophiles living in AMD. As determined in previous studies, the AMD microbial community changes over time (McGinnes and Johnson, 1993; Edwards et al., 1999; Volant et al., 2014). The variety of microbial community is attached to seasonal changes and environmental conditions in AMD (Auld et al., 2017).

Classical microbial ecology methods remain limited in determining microbial diversity. Therefore, culture-independent methods such as 16s rRNA gene cloning, fluorescent in situ hybridization (FISH) and denaturing gradient ge electrophoresis (DGGE) are often used to investigate the diversity of microbia community that adapts to this unique environments (Gonzalez-Toril et al., 2003; Nicomrat et al., 2006; Garcia-Moyano et al., 2015). Acidophilic chemolithotrophs such as Acidithiobacillus ferrooxidans, Acidithiobacillus thiooxidans, Leptospirillium ferrooxidans have been identified in AMD which extremely low $\mathrm{pH}$ and high concentrations of iron, sulfates and other heavy metals (Edwards et al., 1999; Kuang et al., 2012). At the same time, the investigation of microbial community by molecular methods is difficult because of the inhibition of PCR by metals such as Fe and Cu (Nicomrat et al., 2006). For the reason, DGGE and 16s rRNA gene cloning methods are used together to support each other in determining the microbial diversity of AMD.

The aim of this research was to determine the acidophilic prokaryotic community of acid mine drainage in ore enrichment plant Halıöy, İzmir (Turkey). Our study area in Halıköy is within the Menderes Massif in western Turkey. The antimony mine was discovered in 1870 and continued to operate until 1918 in Halıöy area. After a long-standing period, production began again in 1974 (Akcay $\boldsymbol{e t}$ al., 2006). Our results are the first knowledge about the prokaryotic community of the selected AMD area.

\section{MATERIALS AND METHODS}

\section{Site description and sample collection}

The water samples were collected from the operating antimony mine, ore enrichment plant Halıköy site $\left(38^{\circ} 5^{\prime} 28.09^{\prime} \mathrm{N}, 28^{\circ} 10^{\prime} 09.6^{\prime \prime} \mathrm{E}\right)$ in İzmir, Turkey (Fig 1), in two different time (March 2014 and June 2015). The samples were taken three different points from mine area as drainage water (sample \#1 and sample \#4), iron oxide pool water (sample \#2 and sample \#5), and stationary water before iron oxide pool (sample \#3 and sample \#6) (Fig 2). Water samples were taken in sterile Duran bottles and were filtered from 0.2 um GTTP filter. In situ measurements for $\mathrm{pH}$ were made using a WTW Multi350i/SET (WTW, Germany). Metal concentrations of water samples were measured by inductively coupled plasma atomic emission spectrometry (ICP-AES).

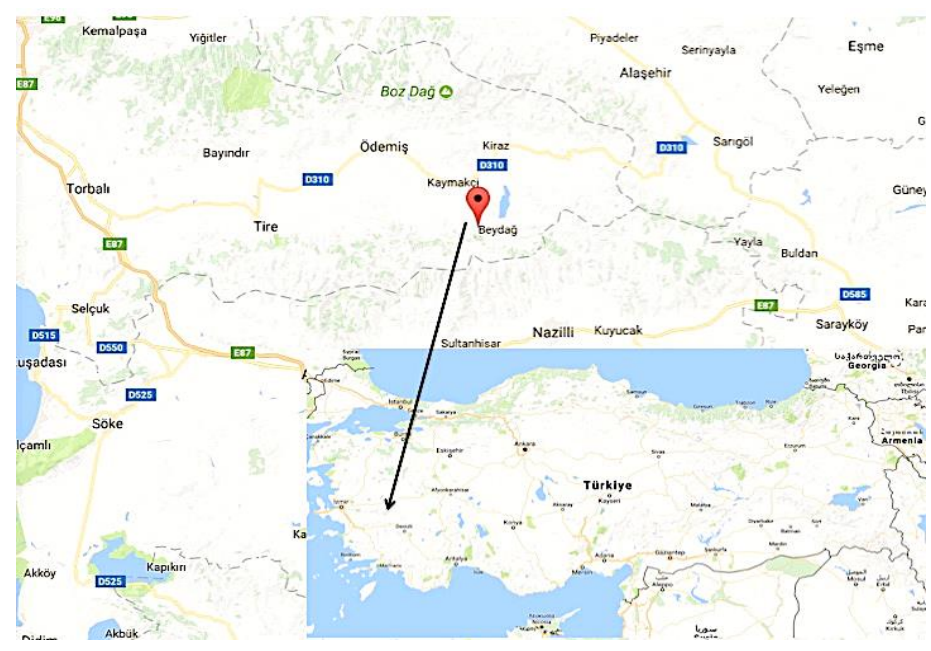

Figure 1 Map of Halıköy, İzmir (Turkey), where AMD ponds are located in antimony mine site 


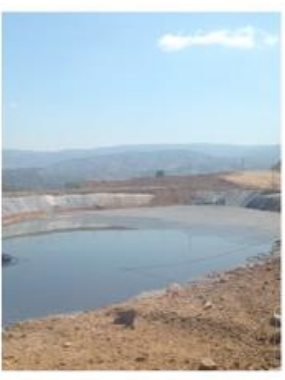

a

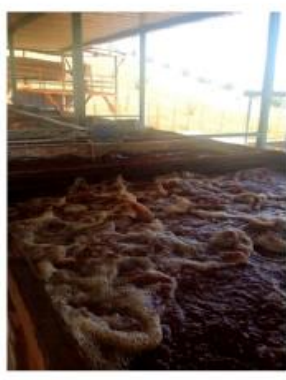

b

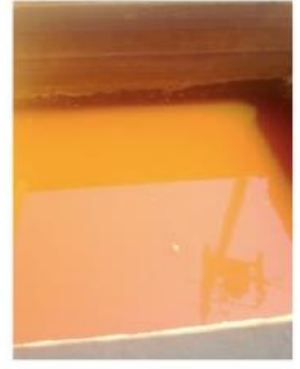

C
Figure 2 Points of water samples (a: \#1 and \#4; b: \#2 and \#5; c: \#3 and \#6)

DNA isolation and 16S rRNA gene amplification

DNA isolations were performed following the procedure explained by Cifuentes et al. (2000) and Nogales et al. (1999) as modified. We used the primer set $27 \mathrm{~F}$ (AGAGTTTGATCMTGGCTCAG)-1387R (GGGCGG(AT)GTGTACAAGGC) and 20F (AGAGTTTGATC(AC)TGGCTCAG)-915R (GTGCTCCCCCGCCAATTCCT) for bacteria and archaea, respectively.

PCR cycles were as follows: one cycle at $95{ }^{\circ} \mathrm{C}$ for five minutes, 30 cycles at 95 ${ }^{\circ} \mathrm{C}$ for 30 seconds, one minute at the corresponding annealing temperature $55{ }^{\circ} \mathrm{C}$ and $62{ }^{\circ} \mathrm{C}$ (for bacteria and archaea, respectively) and $72{ }^{\circ} \mathrm{C}$ for 1.5 minutes, and a final extension step at $72^{\circ} \mathrm{C}$ for ten minutes.

\section{S rRNA gene cloning}

The PCR products were cloned using the pGEM-T easy vector system II and colony PCRs were set up with $27 \mathrm{~F}$ and 1387R; 20F and 907R primer sets of selected colonies, for bacteria and archaea, respectively. Similar profiles were determined by amplified ribosomal DNA restriction analysis (ARDRA) in the $16 \mathrm{~S}$ rRNA gene libraries. Clones were divided into categories $\left(3 \mathrm{~h}, 37^{\circ} \mathrm{C}\right)$ based on pattern generated by the restriction enzymes MspI and HaeIII (5 units each).

\section{DGGE}

Amplification of the 16S rRNA gene was carried out with specific primers for DGGE analysis. Primer set including 344F-GC (CGCCCGCCGCGCCCCGCGCCCGTCCCGCCGCCCCCGCCCGACGGGGC GCAGCAGGCGCGA) and 907R (CCGTCAATTCCTTTGAGTTT) was used for the archaeal gene amplification while for the bacterial gene, the forward primer,

341F-GC (CGCCCGCCGCGCCCCGCGCCCGTCCCGCCGCCCCCGCCCGCCTACGG GAGGCAGCAG) in combination with 907R were used (Muyzer et al., 1993) DGGE PCR condition for bacteria: one cycle at $94{ }^{\circ} \mathrm{C}$ for five minutes, one minute at $65{ }^{\circ} \mathrm{C}$ and three minutes at $72{ }^{\circ} \mathrm{C}$ and nine cycles at $94{ }^{\circ} \mathrm{C}$ for one minute, one minute at the annealing temperature was decrease $64-55^{\circ} \mathrm{C}$ and 72 ${ }^{\circ} \mathrm{C}$ for three minutes, and one cycle at $94{ }^{\circ} \mathrm{C}$ for five minutes, one minute at 55 ${ }^{\circ} \mathrm{C}$ and three minutes at $72{ }^{\circ} \mathrm{C}$ and a final step $94{ }^{\circ} \mathrm{C}$ for five minutes, one minute at $55^{\circ} \mathrm{C}$ and ten minutes at $72{ }^{\circ} \mathrm{C}$. DGGE PCR condition for archaea: one cycle at $94{ }^{\circ} \mathrm{C}$ for five minutes, 29 cycles at $94{ }^{\circ} \mathrm{C}$ for three seconds, $56{ }^{\circ} \mathrm{C}$ for 45 seconds, $72{ }^{\circ} \mathrm{C}$ for two minutes, and one cycle at $94{ }^{\circ} \mathrm{C}$ for 30 seconds, $56{ }^{\circ} \mathrm{C}$ for 45 seconds, $72{ }^{\circ} \mathrm{C}$ for seven minutes. The PCR products were purified with the Wizard SV Gel and PCR Clean-Up System (Promega, Italy).

Denaturing gradient gel electrophoresis (DGGE) was performed with the DCode Universal Mutation Detection System (Bio-Rad Laboratories, Inc.). PCR product was loaded on $1 \mathrm{~mm}$ thick $8 \%(\mathrm{w} / \mathrm{v})$ polyacrylamide (37.5: acrylamide: bisacrylamide) gels containing a 45-60\% linear denaturing gradient Gels were run in $1 \mathrm{X}$ TAE buffer at $60^{\circ} \mathrm{C}$ and $90 \mathrm{~V}$ for $18 \mathrm{~h}$. Gels were stained in 1X TAE buffer containing ethidium bromide solution $(1 \mu \mathrm{g} / \mathrm{ml})$ and photographed under UV transillumination.

Each band in different positions was cut with a sterile lancet from the polyacrylamide gel and was stored at $37{ }^{\circ} \mathrm{C}$ in solvent buffer (ammonium acetate $5 \mathrm{M}$, magnesium acetate $10 \mathrm{mM}$, EDTA (pH 8.0) $1 \mathrm{mM}$, SDS $0.1 \%$ ) during overnight and DNA fragments were isolated. The DNA fragments were used reamplification with same primer pairs without GC clamps and were sequenced.

\section{Accession numbers and construction phylogenetic tree of nucleotide sequences}

Multiple gene alignments were applied using MUSCLE software. Phylogenetic trees were made using MEGA version 7 and the neighbor-joining method (Saitou and Nei, 1987). The $16 \mathrm{~S}$ rRNA gene sequences and results of DGGE analyses were uploaded into the GenBank Database.

\section{RESULTS}

\section{Characteristics of site and samples}

The sampling site is antimony mine site being operated. The AMD samples were characterized by acidic $\mathrm{pH}$ values ranging from 2.7 to 6.5 and high concentrations of dissolved metals (Table 1). The sample points show the typica orange and red colors of dissolved ferric iron as shown in Figure 1. It was determined that the samples had high iron, zinc, lead and manganese ratios. Treatment and neutralization studies of outlet water caused increase the $\mathrm{pH}$ value and decrease iron concentration between two sampling times (sample \#5). This $\mathrm{pH}$ change also affected the prokaryotic diversity at the sample site (Table 1).

Table $1 \mathrm{pH}$ values and dissolved metal concentrations of water samples

\begin{tabular}{lllllll}
\hline \multirow{2}{*}{ Samples code- $\mathbf{p H}$} & $\# 1$ & $\# 2$ & $\# 3$ & $\# 4$ & $\# 5$ & $\# 6$ \\
& 3.0 & 2.9 & 2.7 & 2.8 & 6.5 & 3.6 \\
\hline Elements & \multicolumn{6}{l}{ Concentrations $\left(\mathbf{m g ~ L}^{-1}\right)$} \\
$\mathrm{ne}$ & 205.3 & 237.8 & $*$ & 198.4 & 40.959 & 200.7 \\
$\mathrm{Zn}$ & 1.693 & 7.547 & 28.98 & 2.006 & 5.328 & 15.952 \\
$\mathrm{Mn}$ & 4.701 & $*$ & $*$ & 4.351 & 8.937 & $*$ \\
$\mathrm{Cr}$ & 0.185 & 0.302 & 0.784 & 0.145 & 0.267 & 0.935 \\
$\mathrm{Co}$ & 0.066 & 1.794 & 6.643 & 0.045 & 1.539 & 5.628 \\
$\mathrm{Cu}$ & 0.077 & 0.820 & 1.637 & 0.058 & 0.754 & 1.756 \\
$\mathrm{Ni}$ & 0.241 & 1.624 & 6.481 & 0.321 & 0.954 & 4.522 \\
$\mathrm{~Pb}$ & 0.029 & 0.065 & 0.063 & 0.019 & 0.017 & 0.052 \\
\hline
\end{tabular}

*Not determined because it has a high concentration.

\section{Cloning}

Clone library technique offers the opportunity to do very sensitive taxonomic studies. By this method, uncultured and unspecified microorganisms are also possible to define (Sanz and Kochling, 2007). The clones from sample \#1 and \#3 YT_K1, YT_2, YT_K12, YT_K14, YT_K16 matched with an uncultured bacterium (\%99), an uncultured archaeon (\%97), Acidithiobacillus ferrivorans (\%99), Acidithiobacillus ferriphilus (\%99), and Acidiphilium rubrum respectively. According to ARDRA of the plasmid insert, it has been determined that there are 4 and 14 different profiles from sample \#2 and \#5 (same points, different periods) coded samples taken in March 2014 and June 2015, respectively (Fig. 3). The sequence of clones (from water samples \#2) YT_K3, YT_K4, YT_K7, and YT_K8 showed 99\% similarities with Acidiphilium sp. Acidithiobacillus ferriphilus, Acidocella sp., Acidiphilium angustrum, respectively. Clones from water sample \#3, YT_K12 and YT_K13 matched with Acidithiobacillus ferrivorans (similarity 99\%), YT_K14 and YT_K16 matched with Acidithiobacillus ferriphilus, Acidiphilium rubrum (similarity 99\%), respectively. The archaeal profile was only determined on AMD samples \#1 and \#3. According to the results of sequence analysis the clones YT K11, and YT_K20 matched with Ferroplasma acidiphilium (similarity 99\%), and clone YT_K9 showed 99\% similarities with Thermoplasmatales archaeon. Other clones from water samples \#4 and \#6 showed $99 \%$ similarities with Acidiphilium sp. and Thiomonas sp. The sequencing results of the clones were given in Table 2.
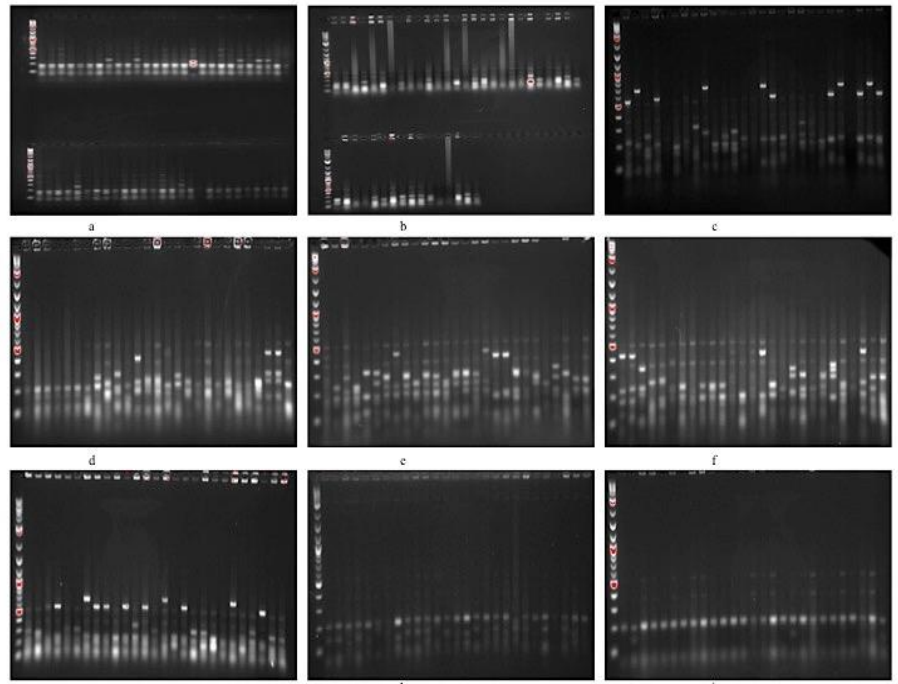

Figure 3 ARDRA profiles of water samples (for bacteria: a, b, c, d, e, f, g: \#1, \#2 \#3, \#4, \#5, \#6; for archaea: h, i: \#1, \#3 respectively). 
Table 2 Prokaryotes16S rRNA gene clones of environmental water samples and their closest matches in GenBank

\begin{tabular}{|c|c|c|c|c|c|}
\hline Clone no & $\begin{array}{l}\text { GenBank } \\
\text { accession no }\end{array}$ & Organism & $\begin{array}{l}\text { Water } \\
\text { sample no }\end{array}$ & $\begin{array}{l}\text { 16S rRNA Gene } \\
\text { Sequence Similarity }(\%)\end{array}$ & $\begin{array}{l}\text { Number of } \\
\text { sequencing base }\end{array}$ \\
\hline YT_K1 & MH057124 & $\begin{array}{l}\text { Uncultured bacterium partial 16S rRNA gene, clone BioPlate3_A12 } \\
\text { HE587229.1 }\end{array}$ & 1 & $99 \%$ & 754 \\
\hline YT_K2 & MH057125 & $\begin{array}{l}\text { Uncultured archaeon gene for } 16 \mathrm{~S} \text { rRNA, partial sequence, clone: } \\
\text { HO28S9A63 AB600346.1 }\end{array}$ & 1 & $97 \%$ & 650 \\
\hline YT_K3 & MH057126 & $\begin{array}{l}\text { Acidiphilium sp. DBS4-1 16S ribosomal RNA gene, partial sequence } \\
\text { EU003879.1 }\end{array}$ & 2 & $99 \%$ & 1004 \\
\hline YT_K4 & MH057127 & $\begin{array}{l}\text { Acidithiobacillus ferriphilus strain DSM } 100412 \text { tyrosyl-tRNA synthetase } \\
\text { gene, complete cds; KY002491.1 }\end{array}$ & 2 & $99 \%$ & 850 \\
\hline YT_K7 & MH057128 & $\begin{array}{l}\text { Acidocella sp. M21 } 16 \mathrm{~S} \text { ribosomal RNA gene, partial sequence } \\
\text { AY765998.1 }\end{array}$ & 2 & $99 \%$ & 854 \\
\hline YT_K8 & MH057129 & $\begin{array}{l}\text { Acidiphilium angustum strain Colony6 } 16 \text { S ribosomal RNA gene, partial } \\
\text { sequence KC } 924944.1\end{array}$ & 2 & $99 \%$ & 873 \\
\hline YT_K9 & MH057130 & $\begin{array}{l}\text { Uncultured Thermoplasmatales archaeon clone B_DKE } 16 \mathrm{~S} \text { ribosomal } \\
\text { RNA gene, partial sequence KY825129.1 }\end{array}$ & 3 & $99 \%$ & 546 \\
\hline YT_K10 & MH057131 & $\begin{array}{l}\text { Uncultured archaeon clone AMD-archD26 16S ribosomal RNA gene } \\
\text { sequence KC537536.1 }\end{array}$ & 3 & $98 \%$ & 941 \\
\hline YT_K11 & MH057132 & Ferroplasma acidiphilum strain Y, complete genome CP015363.1 & 3 & $99 \%$ & 809 \\
\hline YT_K12 & MH057133 & $\begin{array}{l}\text { Acidithiobacillus ferrivorans strain NO-37 16S ribosomal RNA gene, } \\
\text { partial sequence NR_114620.1 }\end{array}$ & 3 & $99 \%$ & 1024 \\
\hline YT_K13 & MH057134 & Acidithiobacillus ferrivorans SS3, complete genome CP002985.1 & 3 & $99 \%$ & 704 \\
\hline YT_K14 & MH057135 & $\begin{array}{l}\text { Acidithiobacillus ferriphilus strain DSM } 100412 \text { tyrosyl-tRNA synthetase } \\
\text { gene, complete cds; KY002491.1 }\end{array}$ & 3 & $99 \%$ & 1010 \\
\hline YT_K16 & MH057136 & $\begin{array}{l}\text { Acidiphilium rubrum strain Colony11 16S ribosomal RNA gene, partial } \\
\text { sequence KC } 924949.1\end{array}$ & 3 & $99 \%$ & 1016 \\
\hline YT_K17 & MH057137 & $\begin{array}{l}\text { Uncultured Thiomonas sp. clone dw10 16S ribosomal RNA gene, partial } \\
\text { sequence KF287769.1 }\end{array}$ & 4 & $99 \%$ & 865 \\
\hline YT_K18 & MH057138 & $\begin{array}{l}\text { Uncultured bacterium clone RT11-ant10-e08-W 16S ribosomal RNA gene, } \\
\text { partial sequence JF737920.1 }\end{array}$ & 4 & $100 \%$ & 862 \\
\hline YT_K20 & MH057139 & $\begin{array}{l}\text { Ferroplasma acidiphilum strain DX-m 16S ribosomal RNA gene, partial } \\
\text { sequence KX694511.1 }\end{array}$ & 3 & $99 \%$ & 747 \\
\hline YT_K21 & MH057140 & $\begin{array}{l}\text { Uncultured bacterium clone NSC0m-bac_d12 16S ribosomal RNA gene, } \\
\text { partial sequence KC619550.1 }\end{array}$ & 4 & $98 \%$ & 671 \\
\hline YT_K23 & MH057141 & $\begin{array}{l}\text { Uncultured bacterium partial 16S rRNA gene, clone BioPlate2_H11 } \\
\text { HE587131.1 }\end{array}$ & 4 & $95 \%$ & 894 \\
\hline YT_K25 & MH057142 & $\begin{array}{l}\text { Acidiphilium multivorum strain AIU301 16S ribosomal RNA gene, } \\
\text { complete sequence NR_074327.1 }\end{array}$ & 4 & $99 \%$ & 877 \\
\hline YT_K27 & MH057143 & $\begin{array}{l}\text { Uncultured bacterium clone LRE22B44 16S ribosomal RNA gene, partial } \\
\text { sequence HQ420129.1 }\end{array}$ & 4 & $99 \%$ & 963 \\
\hline YT_K28 & MH057144 & Acidiphilium cryptum JF-5, complete genome CP000697.1 & 4 & $99 \%$ & 824 \\
\hline YT_K29 & MH057145 & $\begin{array}{l}\text { Uncultured bacterium clone A13 16S ribosomal RNA gene, partial } \\
\text { sequence KF031176.1 }\end{array}$ & 5 & $98 \%$ & 805 \\
\hline YT_K30 & MH057146 & $\begin{array}{l}\text { Uncultured alpha proteobacterium clone AKYG835 16S ribosomal RNA } \\
\text { gene, partial sequence AY922070.1 }\end{array}$ & 5 & $99 \%$ & 809 \\
\hline YT_K31 & MH057147 & $\begin{array}{l}\text { Uncultured bacterium clone BE326_BF2_otu4 16S ribosomal RNA gene, } \\
\text { partial sequence JX298447.1 }\end{array}$ & 5 & $96 \%$ & 848 \\
\hline YT_K32 & MH057148 & $\begin{array}{l}\text { Uncultured bacterium clone BDP28WS24 16S ribosomal RNA gene, } \\
\text { partial sequence KF841202.1 }\end{array}$ & 5 & $98 \%$ & 668 \\
\hline YT_K33 & MH057149 & $\begin{array}{l}\text { Uncultured bacterium clone T7-82 16S ribosomal RNA gene, partial } \\
\text { sequence GQ487952.1 }\end{array}$ & 5 & $99 \%$ & 857 \\
\hline YT_K34 & MH057150 & $\begin{array}{l}\text { Uncultured beta proteobacterium clone } 220 \mathrm{~T} 36 \text { 16S ribosomal RNA gene, } \\
\text { partial sequence DQ110071.1 }\end{array}$ & 5 & $98 \%$ & 816 \\
\hline YT_K35 & MH057151 & $\begin{array}{l}\text { Uncultured bacterium partial 16S rRNA gene, clone Iron-rich microbial } \\
\text { mat clone Hoffnungsstollen_\#5-1A_E11 LN870830.1 }\end{array}$ & 5 & $96 \%$ & 726 \\
\hline YT_K36 & MH057152 & $\begin{array}{l}\text { Uncultured bacterium clone SX2-12 } 16 \mathrm{~S} \text { ribosomal RNA gene, partial } \\
\text { sequence DQ469219.1 }\end{array}$ & 5 & $99 \%$ & 858 \\
\hline YT_K37 & MH057153 & $\begin{array}{l}\text { Uncultured bacterium clone EPS09_OK_001A_57 16S ribosomal RNA } \\
\text { gene, partial sequence JX521231.1 }\end{array}$ & 5 & $99 \%$ & 838 \\
\hline YT_K38 & MH057154 & $\begin{array}{l}\text { Uncultured bacterium clone F-19 16S ribosomal RNA gene, partial } \\
\text { sequence HQ132424.1 }\end{array}$ & 5 & $97 \%$ & 702 \\
\hline YT_K40 & MH057155 & $\begin{array}{l}\text { Uncultured bacterium clone SH201209-31 16S ribosomal RNA gene, } \\
\text { partial sequence KX508591.1 }\end{array}$ & 5 & $98 \%$ & 646 \\
\hline YT_K41 & MH057156 & $\begin{array}{l}\text { Uncultured bacterium clone SX2-10 16S ribosomal RNA gene, partial } \\
\text { sequence DQ469201.1 }\end{array}$ & 5 & $99 \%$ & 752 \\
\hline YT_K42 & MH057157 & $\begin{array}{l}\text { Uncultured bacterium clone AMD1-Plate1-B06 16S ribosomal RNA gene, } \\
\text { partial sequence JN127499.1 }\end{array}$ & 5 & $99 \%$ & 455 \\
\hline YT_K43 & MH057158 & $\begin{array}{l}\text { Uncultured bacterium clone BCWCWP1A42 16S ribosomal RNA gene, } \\
\text { partial sequence FJ598380.1 }\end{array}$ & 5 & $99 \%$ & 925 \\
\hline YT_K44 & MH057159 & $\begin{array}{l}\text { Acidiphilium sp. BGR 75a 16S ribosomal RNA gene, partial sequence } \\
\text { GU167999.1 }\end{array}$ & 6 & $99 \%$ & 843 \\
\hline YT_K45 & MH057160 & $\begin{array}{l}\text { Uncultured Thiomonas sp. clone S-K6-C18 } 16 \mathrm{~S} \text { ribosomal RNA gene, } \\
\text { partial sequence EF612428.1 }\end{array}$ & 6 & $99 \%$ & 878 \\
\hline YT_K46 & MH057161 & $\begin{array}{l}\text { Uncultured bacterium partial 16S rRNA gene, clone BioPlate2_G10 } \\
\text { HE587210.1 }\end{array}$ & 6 & $99 \%$ & 798 \\
\hline YT_K47 & MH057162 & $\begin{array}{l}\text { Uncultured bacterium partial 16S rRNA gene, clone BioPlate2_A10 } \\
\text { HE587139.1 }\end{array}$ & 6 & $99 \%$ & 827 \\
\hline
\end{tabular}




\section{DGGE}

DGGE analyses were performed with each different sample to determine the level of microbial diversity in the mine area. (Fig 4). The samples collected from the same sample points determined to have different profiles. Especially, due to $\mathrm{pH}$ change, it was found that bacterial diversity quite different sample $\# 5$ and sample \#2. Blast analyses of DGGE bands sequences are given in Table 3. Archaeal diversity was determined only in sample \#1 and sample \#3. The sequence of bands YT_D1, YT_D2, YT_D3, YT_D4, and YT_D5 showed similarity with uncultured archaeon clones, as a show that in Table 3. Differences were observed in the DGGE profiles of taken water samples at different times from the same sampling points. It was determined that the sample \#4 have more bacterial diversity from sample \#1. According to sequence analysis results, there are bands matched with Ferrovum myxofaciens, Acidithiobacillus ferrooxidans, Acidithiobacillus ferrivorans, Acidithiobacillus ferriphilus and uncultured Acidithiobacillus sp. in sample \#1. In the case of water sample \#4, it was determined that the majority of the species are Acidocella (Table 3). Although samples \#2 and \#5 were taken from the same spot, it was thought that the change in $\mathrm{pH}$ at sample \#5 caused the formation of different profiles. Bands at sample \#5 were showed similarity with Acidocella aluminiidurans, uncultured Acidocella sp. and uncultured Acidiphilium sp. In sample \#3, bacterial diversity is less than in sample \#6. The band of sample \#6, it was determined to match with Thiomonas sp. (Table 3).

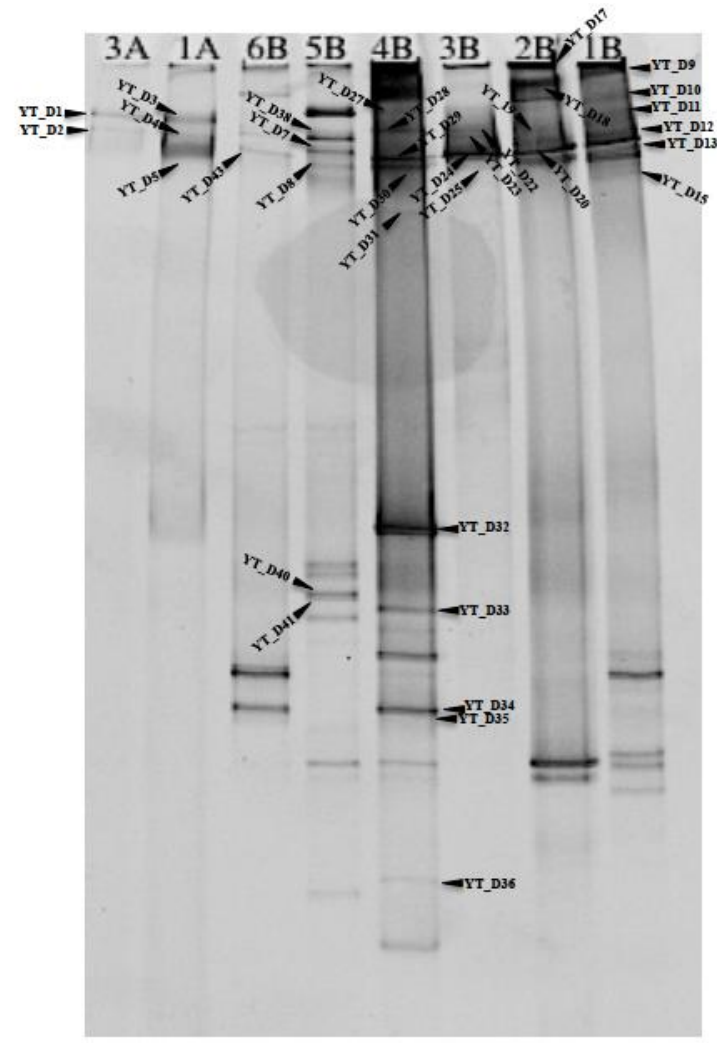

Figure 4 DGGE profiles of the AMD water samples.

\section{Accession numbers and construction phylogenetic tree of nucleotide sequences}

16S rRNA gene sequences were deposited in GenBank under accession numbers MH057089-H057162. In order to determine the phylogenetic group, the phylogenetic tree was constructed with sequences obtained by 16 rRNA clone library and DGGE analyses (Fig 5, 6).

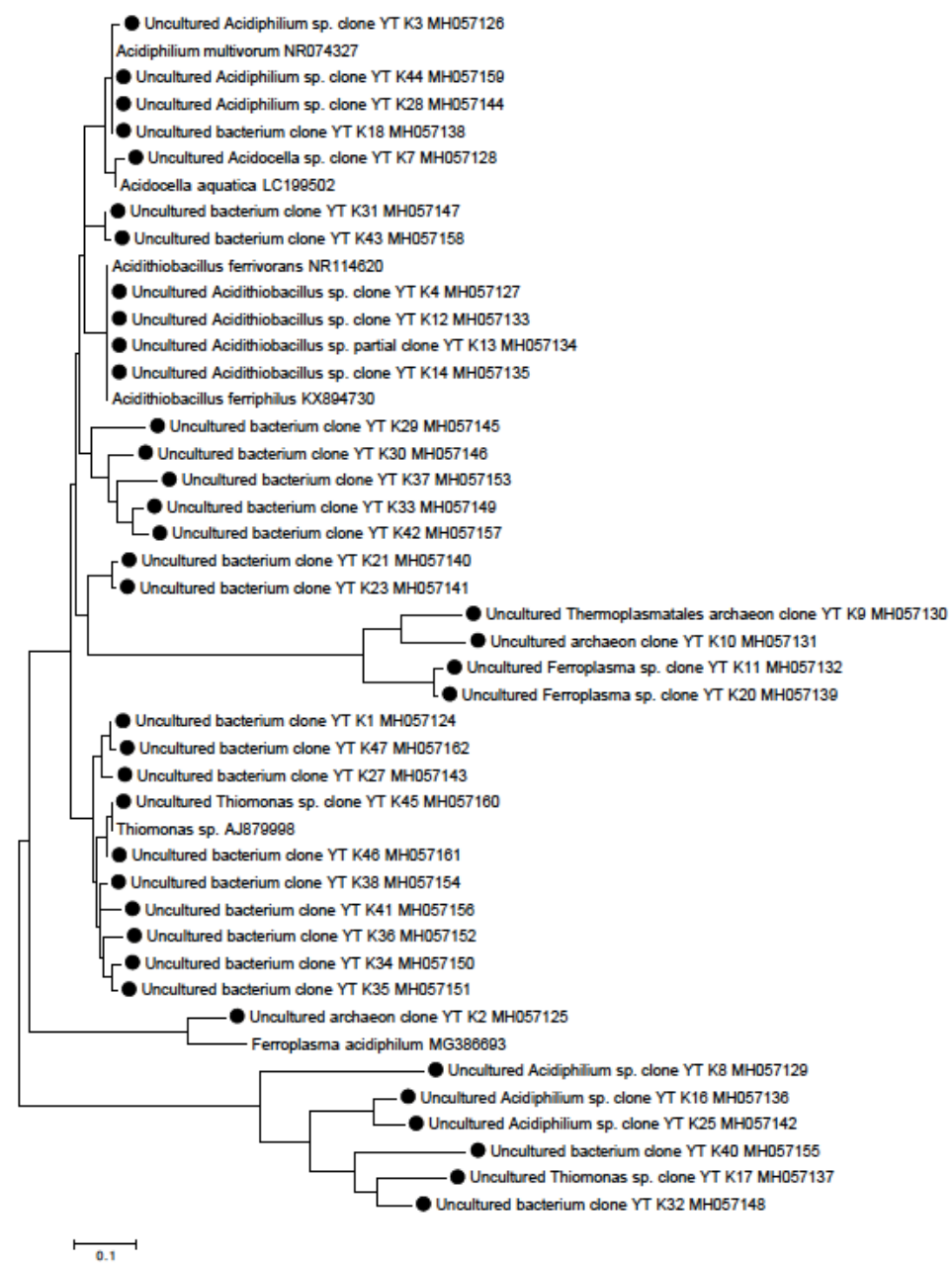

Figure 5 Phylogenetic tree based on 16S rRNA gene sequences of 16S rRNA clone libraries. 
Table 3 Prokaryotes of environmental water samples closest matches of DGGE bands in GenBank

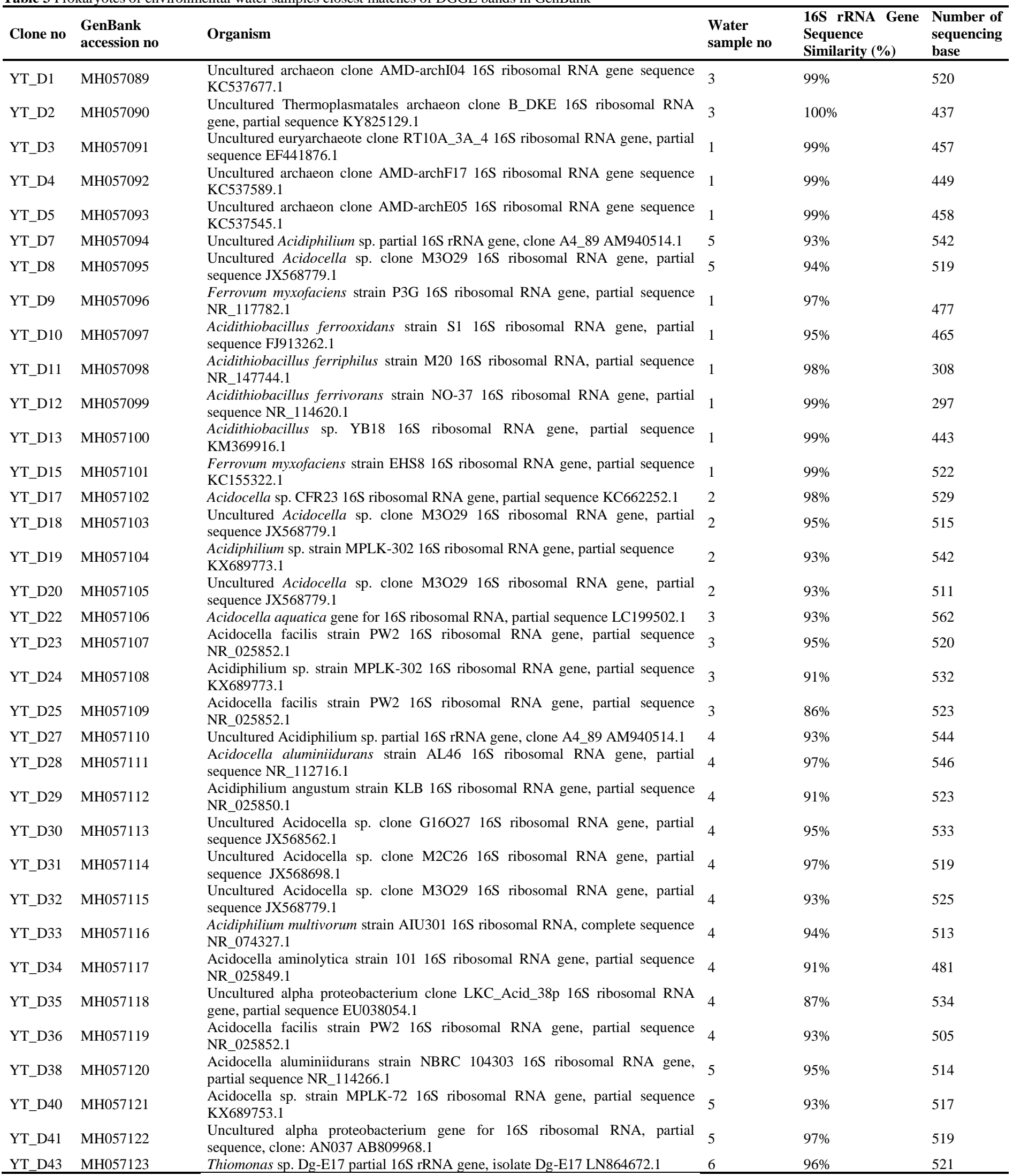




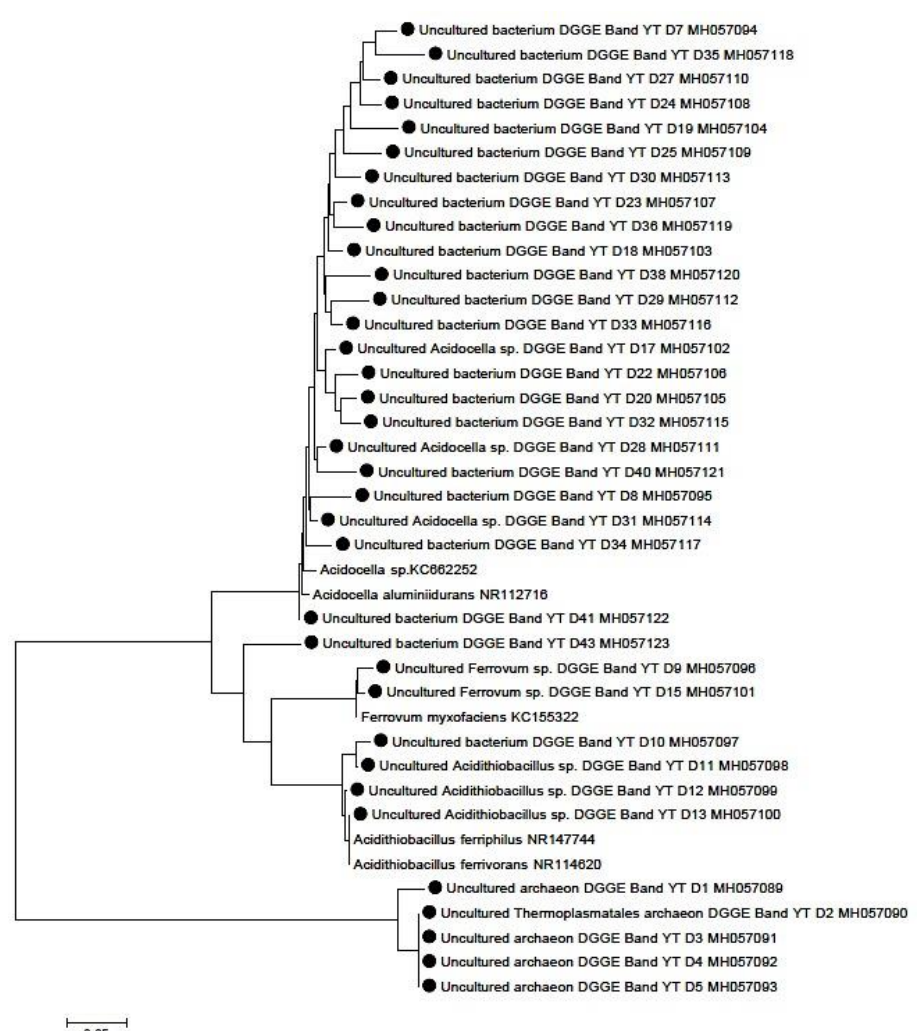

Figure 6 Phylogenetic tree based on 16S rRNA gene sequences of DGGE bands.

\section{DISCUSSION}

Determining of communities in AMD provides important clues in terms of the diversity and functions of these organisms with the development of molecular approaches. Furthermore, the development of sequencing technologies is rare in acidic environments allowing the identification of numerous taxa found (Kuang et al., 2012; Aliaga Goltsman et al., 2014).

The $\mathrm{pH}$ value and metal concentrations of the AMD ponds seem to be suitable for existence in the determined species. Especially, high iron concentration is determinant for the life of species such as Acidithiobacillus ferrivorans, Aciditihobacillus ferriphilus. Mendez and coworkers have determined Acidithiobacillus ferrivorans with similar properties samples $(\mathrm{pH} 2.7$, Fe: 38.100 $\mathrm{mg} \mathrm{kg}^{-1}$ ) (Mendez et al., 2008). One of the sequences identified in the study of microbial diversity of Xiang Mountain sulfide mine was matched with Ferrovum myxofaciens, which was recently isolated from an abandoned copper mine $(\mathrm{pH}$ 3.0, Fe: $100.6 \mathrm{mg} \mathrm{L}^{-1}$ ) (Hao et al., 2010). Acidiphilium sp. was determined by community composition analysis in acid mine drainage from Fankou $\mathrm{Pb} / \mathrm{Zn}$ mine, China (pH 1.9, Fe $1240 \mathrm{mg} \mathrm{L}^{-1}$ ) (Chen et al., 2014,a).

Autotrophic and heterotrophic groups were identified from selected sample points in this study. It is noteworthy that archaea domain members cannot be determined from samples \#4 and \#6 in June 2015, while the archaea were determined in March 2014 (samples \#1 and \#3). It is thought that this may be due to the continuing effects of the mining activity. Changes in the environment created by anthropogenic effects are rapidly affecting microbial diversity. Ferroplasma spp., which was identified in this study, has been determined as dominant after the period of the acidification processes of mine wastes (Chen $\boldsymbol{e t}$ al., 2013; Chen et al., 2014,b).

As seen in Figure 7, the variety of prokaryotic diversity was observed by used molecular techniques in AMD ponds. As one of the reasons for this, some of the technical difficulties of the methods used can be shown. While sequencing over a short region of DNA by the DGGE method, the cloning longer base chain can be evaluated. With all of these drawbacks, both methods complement each other's deficiencies so that can determine the prokaryotic diversity of AMD ponds to a significant extent. For example, Ferroplasma sp., Thiomonas sp. species could be identified only by $16 \mathrm{~S}$ cloning, while Ferrovum sp. could be identified only by DGGE method. Other less frequently detected bacterial taxa the heterotrophic growers Thiomonas spp. (Chen et al., 2016) that has been isolated was not detected by molecular techniques, probably reflecting its low abundance (Bruneel et al., 2005).

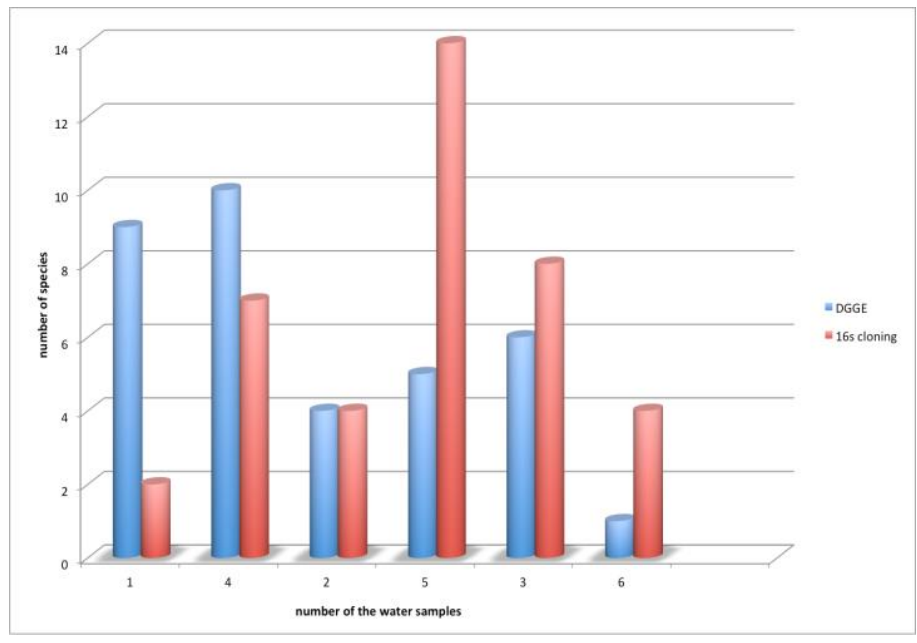

Figure 7 The diversity profile of AMD ponds obtained by 16S rRNA clone libraries and DGGE methods.

Gonzalez-Toril and collaborates studied by DGGE using 16S rRNA and, by $16 \mathrm{~S}$ rRNA gene amplification for research molecular ecology an extreme acidic Tinto River (Spain). Comparative sequence analysis of DGGE bands determined the entity of the respective microorganisms like Leptospirillum spp. Acidithiobacillus ferrooxidans, Acidiphilium spp., Ferrimicrobium acidiphilum, Ferroplasma acidiphilum, and Thermoplasma acidophilum (Gonzalez-Toril et al., 2003). Aytar and coworkers have identified prokaryotic diversity in two different AMD sites (Balya and Çan) in Turkey (Aytar et al., 2014). Some species identified in this study were as Acidithiobacillus sp., Leptosipirillum sp., Ferooplasma sp. Saglam and colleagues determined bacterial diversity in the Acisu effluent with cloning 16s rRNA sequences. The bacterial population was identified to occur Acidithiobacillus ferrivorans, Ferrovum myxofaciens, Leptospirillum ferrooxidans, Acidithiobacillus ferrooxidans, Acidocella facilis, Acidocella aluminiidurans, Acidiphilium cryptum, Acidiphilium multivorum, Acidithiobacillus ferrivorans, Acidithiobacillus ferrooxidans, Acidithiobacillus thiooxidans, Acidiphilium cryptum (Saglam et al., 2016)

Alphaproteobacteria (Acidiphilium, Acidocella) (Liu et al., 2011; Falagan et al., 2013), Betaproteobacteria (Thiomonas, Ferrovum), (Mendez et al., 2008; Johnson et al., 2013), Acidithiobacillia (Acidithiobacillus) (Williams and Kelly, 2013) are seen in other studies. Betaproteobacteria, mostly belonging to the 'Ferrovum' genus, was clearly predominant in the community below middle $\mathrm{pH}$ conditions, whereas Alphaproteobacteria, Euryarchaeota, Gammaproteobacteria, and Nitrospira exposed a powerful adaptation to more acidic conditions (Kuang et al., 2012).

As a result of matches, it has been determined that some sequences are similar to those of Aciditihobacillus ferriphilus (Nunez et al., 2017), Acidiphilium angustum, and Acidiphilium rubrum (Auld et al., 2013). These species are new records for Turkey. The iron-oxidizing acidithiobacilli Acidithiobacillus ferriphilus was also isolated from different global locations such as metal-rich waters sample deep within the mine (Kay et al., 2014). The type strain $\mathrm{M} 20^{\mathrm{T}}$ was isolated from a pond in a geothermal area of Montserrat ( $\mathrm{pH}$ 1.5-3.0) (West Indies) which lived optimally $\mathrm{pH} 2.0$ and $30{ }^{\circ} \mathrm{C}$ of temperature (Atkinson $\boldsymbol{e t}$ al. 2000). It was determined later that this strain separated from other acidithiobacilli (Falagan and Johnson, 2016). The clones and DGGE bands sequences showed to match the most Acidiphilium genus. The mesophilic and obligately acidophilic bacteria Acidiphilium angustum grow in the $\mathrm{pH}$ range of 2.0-5.9. The clone YT_K8 matched with Acidiphilium angustum (99\% similarity) was obtained from water sample \#2 (pH 2.9). Auld and coworkers have isolated Acidiphilium rubrum from an AMD site in Copper Cliff, Ontario (Auld et al., 2013). The isolate was isolated from $A M D$ water at $\mathrm{pH} 2.5$, similar to the water sample (pH 2.7) in which identified YT_K16.

\section{CONCLUSION}

Future studies will focus on the roles of these species on the biogeochemica cycles of the region where microbial diversity is determined. The AMD is also likely to contain new species. To better understand community dynamics in acid formation, more studies are needed to identify predominant species in AMD environments.

Acknowledgment: This study is based partly on the Ph.D. thesis of Y. Toptas Also, the study was supported by Eskisehir Osmangazi University, Scientific Research Projects Committee (Project No: 2016/19A223). 


\section{REFERENCES}

Akçay, M., Özkan, H. M., Moon, C. J., \& Spiro, B. (2006). Geology, mineralogy and geochemistry of the gold-bearing stibnite and cinnabar deposits in the Emirl and Halıköy areas (Ödemiş, İzmir, West Turkey). Ore Geology Reviews, 29(1), 19-51. http://doi:10.1016/j.oregeorev.2004.12.006

Aliaga Goltsman, D. S., Comolli, L. R., Thomas, B. C., \& Banfield, J. F. (2014) Community transcriptomics reveals unexpected high microbial diversity in acidophilic biofilm communities. The ISME Journal, 9(4), 1014-1023 http://doi:10.1038/ismej.2014.200

Atkinson, T., Cairns, S., Cowan, D. A., Danson, M. J., Hough, D. W., Johnson, D. B., ... Sharp, R. J. (2000). A microbiological survey of Montserrat Island hydrothermal biotopes. $\quad$ Extremophiles, 4(5), 305-313. http://doi:10.1007/s007920070018

Auld, R. R., Myre, M., Mykytczuk, N. C. S., Leduc, L. G., \& Merritt, T. J. S. (2013). Characterization of the microbial acid mine drainage microbia community using culturing and direct sequencing techniques. Journal of Microbiological Methods, 93(2), 108-115. http://doi:10.1016/j.mimet.2013.01.023

Auld, R. R., Mykytczuk, N. C. S., Leduc, L. G., \& Merritt, T. J. S. (2017). Seasonal variation in an acid mine drainage microbial community. Canadian Journal of Microbiology, 63(2), 137-152. http://doi:10.1139/cim-2016-0215

Aytar, P., Kay, C. M., Mutlu, M. B., Çabuk, A., \& Johnson, D. B. (2014) Diversity of acidophilic prokaryotes at two acid mine drainage sites in Turkey. Environmental Science and Pollution Research, 22(8), 5995-6003. http://doi:10.1007/s11356-014-3789-4

Bruneel, O., Duran, R., Casiot, C., Elbaz-Poulichet, F., \& Personné, J.-C. (2006) Diversity of Microorganisms in Fe-As-Rich Acid Mine Drainage Waters of Carnoulès, France. Applied and Environmental Microbiology, 72(1), 551-556. http://doi:10.1128/aem.72.1.551-556.2006

Chen, L., Li, J., Chen, Y., Huang, L., Hua, Z., Hu, M., \& Shu, W. (2013). Shifts in microbial community composition and function in the acidification of a lead/zinc mine tailings. Environmental Microbiology, 15(9), 2431-2444. http://doi:10.1111/1462-2920.12114

Chen, L., Hu, M., Huang, L., Hua, Z., Kuang, J., Li, S., \& Shu, W. (2014,a) Comparative metagenomic and metatranscriptomic analyses of microbia communities in acid mine drainage. The ISME Journal, 9(7), 1579-1592. http://doi:10.1038/ismej.2014.245

Chen, Y., Li, J., Chen, L., Hua, Z., Huang, L., Liu, J., ... Shu, W. (2014,b) Biogeochemical Processes Governing Natural Pyrite Oxidation and Release of Acid Metalliferous Drainage. Environmental Science \& Technology, 48(10), 5537-5545. http://doi:10.1021/es500154z

Chen, L., Huang, L., Méndez-García, C., Kuang, J., Hua, Z., Liu, J., \& Shu, W. (2016). Microbial communities, processes and functions in acid mine drainage ecosystems. Current Opinion in Biotechnology, 38, 150-158. http://doi:10.1016/j.copbio.2016.01.013

Cifuentes, A., Antón, J., Benlloch, S., Donnelly, A., Herbert, R. A., \& RodríguezValera, F. (2000). Prokaryotic Diversity in Zostera noltii Colonized Marine Sediments. Applied and Environmental Microbiology, 66(4), 1715-1719. http://doi:10.1128/aem.66.4.1715-1719.2000

Edwards, K. J., Gihring, T. M., \& Banfield, J. F. (1999). Seasonal Variations in Microbial Populations and Environmental Conditions in an Extreme Acid Mine Drainage Environment. Applied and Environmental Microbiology, 65(8), 3627 3632. http://doi:10.1128/aem.65.8.3627-3632.1999

Falagán, C., \& Johnson, D. B. (2016). Acidithiobacillus ferriphilus sp. nov., a facultatively anaerobic iron- and sulfur-metabolizing extreme acidophile. International Journal of Systematic and Evolutionary Microbiology, 66(1), 206211. http://doi:10.1099/ijsem.0.000698

Falagán, C., Sánchez-España, J., \& Johnson, D. B. (2013). New insights into the biogeochemistry of extremely acidic environments revealed by a combined cultivation-based and culture-independent study of two stratified pit lakes. FEMS Microbiology Ecology, 87(1), 231-243. http://doi:10.1111/1574-6941.12218

García-Moyano, A., Austnes, A., Lanzén, A., González-Toril, E., Aguilera, Á., \& Øvreås, L. (2015). Novel and Unexpected Microbial Diversity in Acid Mine Drainage in Svalbard $\left(78^{\circ} \mathrm{N}\right)$, Revealed by Culture-Independent Approaches. Microorganisms, 3(4), 667-694. http://doi:10.3390/microorganisms3040667 González-Toril, E., Llobet-Brossa, E., Casamayor, E. O., Amann, R., \& Amils, R. (2003). Microbial Ecology of an Extreme Acidic Environment, the Tinto River. Applied and Environmental Microbiology, 69(11), 6959-6959. http://doi:10.1128/aem.69.11.6959.2003

Hao, C., Wang, L., Gao, Y., Zhang, L., \& Dong, H. (2010). Microbial diversity in acid mine drainage of Xiang Mountain sulfide mine, Anhui Province, China. Extremophiles, 14(5), 465-474. http://doi:10.1007/s00792-010-0324-5

Johnson, D. B., Hallberg, K. B., \& Hedrich, S. (2013). Uncovering a Microbial Enigma: Isolation and Characterization of the Streamer-Generating, IronOxidizing, Acidophilic Bacterium "Ferrovum myxofaciens." Applied and Environmental Microbiology, 80(2), 672-680. http://doi:10.1128/aem.03230-13

Kay, C.M., Haanela, A., Johnson, D.B. (2014). Microorganisms in subterranean acidic waters within Europe's deepest metal mine. Res Microbiol, 165, 705-712. https://doi.org/10.1016/j.resmic.2014.07.007
Kuang, J. L., Huang, L.N., Chen, L.X., Hua, Z.S., Li, S.J., Hu, M., ... Shu, W.S (2012). Contemporary environmental variation determines microbial diversity patterns in acid mine drainage. The ISME Journal, 7(5), 1038-1050 http://doi:10.1038/ismej.2012.139

Liu, H., Yin, H., Dai, Y., Dai, Z., Liu, Y., Li, Q., ... Liu, X. (2011). The coculture of Acidithiobacillus ferrooxidans and Acidiphilium acidophilum enhances the growth, iron oxidation, and CO2 fixation. Archives of Microbiology, 193(12), 857-866. http://doi:10.1007/s00203-011-0723-8

McGinness, S., \& Barrie Johnson, D. (1993). Seasonal variations in the microbiology and chemistry if an acid mine drainage stream. Science of The Total Environment, 132(1), 27-41. http://doi:10.1016/0048-9697(93)90259-9

Mendez, M. O., Neilson, J. W., \& Maier, R. M. (2008). Characterization of a Bacterial Community in an Abandoned Semiarid Lead-Zinc Mine Tailing Site. Applied and Environmental Microbiology, 74(12), 3899-3907. http://doi:10.1128/aem.02883-07

Muyzer, G., Smalla, K. (1999). Application of denaturing gradient gel electrophoresis (DGGE) and temperature gradient gel electrophoresis in microbial ecology. Antonie van Leeuwenhock, 73, 127-141.

Nicomrat, D., Dick, W. A., \& Tuovinen, O. H. (2006). Assessment of the Microbial Community in a Constructed Wetland that Receives Acid Coal Mine Drainage. Microbial Ecology, 51(1), 83-89. http://doi:10.1007/s00248-005-0267$\underline{z}$

Nogales, B., Moore, E. R. B., Abraham, W.-R., \& Timmis, K. N. (1999) Identification of the metabolically active members of a bacterial community in a polychlorinated biphenyl-polluted moorland soil. Environmental Microbiology, 1(3), 199-212. http://doi:10.1046/j.1462-2920.1999.00024.x

Nuñez, H., Moya-Beltrán, A., Covarrubias, P. C., Issotta, F., Cárdenas, J. P., González, M., ... Quatrini, R. (2017). Molecular Systematics of the Genus Acidithiobacillus: Insights into the Phylogenetic Structure and Diversification of the Taxon. Frontiers in Microbiology, 8. http://doi:10.3389/fmicb.2017.00030 Sağlam, E. S., Akçay, M., Çolak, D. N., İnan Bektaş, K., \& Beldüz, A. O. (2016). Generation of acid mine drainage around the Karaerik copper mine (Espiye, Giresun, NE Turkey): implications from the bacterial population in the Acisu effluent. Extremophiles, 20(5), 673-685. http://doi:10.1007/s00792-016-0857-3 Saitou, N., Nei, M. (1987). The neighbor-joining method: A new method for reconstructing phylogenetic trees. Molecular Biology and Evolution, 4, 406-425. http://doi:10.1093/oxfordjournals.molbev.a040454

Sanz, J. L., and Köchling, T. (2007). Molecular biology techniques used in wastewater treatment: An overview. Process Biochemistry, 42(2), 119-133. http://doi:10.1016/j.procbio.2006.10.003

Volant, A., Bruneel, O., Desoeuvre, A., Héry, M., Casiot, C., Bru, N., ... Lauga, B. (2014). Diversity and spatiotemporal dynamics of bacterial communities: physicochemical and other drivers along an acid mine drainage. FEMS Microbiology Ecology, 90(1), 247-263. http://doi:10.1111/1574-6941.12394

Williams, K. P., \& Kelly, D. P. (2013). Proposal for a new class within the phylum Proteobacteria, Acidithiobacillia classis nov., with the type order Acidithiobacillales, and emended description of the class Gammaproteobacteria International Journal of Systematic and Evolutionary Microbiology, 63(Pt_9), 3547-3548. http://doi:10.1099/ijs.0.057166-0 